\title{
Experimental infection of broiler chicks with Salmonella Typhimurium from pigeon (Columba livia)
}

\section{Infecção experimental em pintos de corte com Salmonella Typhimurium proveniente de pombo (Columba livia)}

\author{
Átilla Holanda de Albuquerque ${ }^{1 *}$; Régis Siqueira de Castro Teixeira ${ }^{1}$; \\ Débora Nishi Machado²; Elisângela de Souza Lopes ${ }^{3}$; Ruben Horn Vasconcelos ${ }^{3}$; \\ Bruno Pessoa Lima ${ }^{4}$; Adson Ribeiro Marques ${ }^{4}$; Isaac Neto Goes da Silva \\ Rosa Patrícia Ramos Salles ${ }^{6}$; William Cardoso Maciel $^{7}$
}

\begin{abstract}
Several cases of animal and human salmonellosis caused by the Salmonella serotype Typhimurium have been reported. In animals, subclinical infection favors pathogen dissemination through feces. In this context, the domestic pigeon (Columba livia) with an asymptomatic condition may play an important role in the transmission of salmonellosis, through the elimination of contaminated feces in commercial aviaries or in poultry feed facilities, causing economic losses to the poultry industry and presenting a risk to public health. This study aimed to evaluate the mortality, clinical signs and the presence of Salmonella Typhimurium in the feces and organs of chicks previously inoculated with bacteria isolated from a pigeon. One-day-old chicks were distributed in two experimental groups (G1 and G2) of 32 birds each, and a control group of six birds. Two inocula of 0.4 and $0.7 \mathrm{~mL}$ with $10^{5}$ and $10^{6}$ colony forming units were used in G1 and G2 birds, respectively. At 1, 4, 7 and 14 days post-inoculation (dpi) fecal samples were pooled from each cage and individual cloacal swabs were collected. At 14 dpi, all chicks were euthanized and samples were collected from the liver, spleen, lung, cecum and intestine for microbiological analysis. Mortality was only observed among G2 birds (6.25\%). Most birds presented clinical signs of diarrhea at $4 \mathrm{dpi}$ and no symptom as observed at $14 \mathrm{dpi}$. The results from cloacal swabs demonstrated bacterial elimination in $68.8 \%$ and $53.1 \%$ of G2 and G1 birds, respectively at 1 dpi. Additionally, fecal samples had elevated bacterial shedding in all four periods of observation , with a higher excretion at 4 dpi (62.5\%) for both groups. Among G2 birds, $74.2 \%$ were positive for the pathogen in the intestine; G1 birds presented the lowest rate of lung infection (29\%), and both groups had more than $50 \%$ positivity for liver and caeca. The results revealed that infected chicks with a Salmonella Typhimurium strains isolated from pigeons may host the pathogen in several organs, and simultaneously present diarrheic disorders with significant levels of bacterial excretion in feces.
\end{abstract}

Key words: Chicks. Experimental infection. Public health. Salmonella Typhimurium.

1 Drs. em Ciências Veterinárias, Programa de Pós-Graduação em Ciências Veterinárias, Universidade Estadual do Ceará, UECE, Fortaleza, CE, Brasil.E-mail: atillaholanda@hotmail.com; regis_siqueira_teixeira@yahoo.com.br

2 M.e em Ciências Veterinárias, Programa de Pós-Graduação em Ciências Veterinárias, UECE, Fortaleza, CE, Brasil. E-mail: deboranishi@gmail.com

3 Discentes de Doutorado em Ciências Veterinárias, Programa de Pós-Graduação em Ciências Veterinárias, UECE, Fortaleza, CE, Brasil. E-mail: elisangeladesouzalopes@hotmail.com; rubenhorn@yahoo.com.br

4 Discentes de Medicina Veterinária, Faculdade de Veterinária, UECE, Fortaleza, CE, Brasil. E-mail: bplima2002@yahoo.com.br; adsonribeiromarques@gmail.com

5 Prof., Patologia Clínica Veterinária, UECE, Fortaleza, CE. Brasil. E-mail: vettings@hotmail.com

6 Dra em Ciências Veterinárias, Médica Veterinária, Biolab Clínica e Laboratório Veterinário LTDA, Fortaleza, CE, Brasil. E-mail: biolab.ce@uol.com.br

7 Prof. Adjunto, Ornitopatologia, Universidade Estadual do Ceará, UECE, Fortaleza, CE, Brasil. E-mail: william.maciel@uol. com.br

Author for correspondence 


\section{Resumo}

Na literatura são relatados diversos casos de salmonelose em animais e humanos em vários países ocasionados pelo sorotipo Typhimurium. Em animais, a infeção subclínica favorece a disseminação do patógeno através das fezes. Nesse contexto, o pombo (Columba livia) com quadro assintomático pode desempenhar um importante papel na transmissão de salmonelose, mediante a excreção de fezes contaminadas em aviários comerciais ou em instalações de ração animal causando perdas econômicas para a indústria avícola, e proporcionando risco para a saúde pública. Objetivou-se avaliar a taxa de mortalidade, sinal clínico e a presença de Salmonella Typhimurium nas fezes e nos órgãos de pintinhos previamente inoculados com bactérias oriundas de pombo. Foram utilizados 70 pintos de corte de um dia de idade, os quais foram distribuídos aleatoriamente em dois grupos (G1 e G2) de 32 aves cada. Utilizou-se um grupo controle, constituído por seis aves, antes do início do tratamento para confirmação da ausência do patógeno. Utilizou-se inóculos de 0,4 e $0,7 \mathrm{~mL}$ contendo as concentrações de $10^{5}$ e $10^{6}$ unidades formadoras de colônias nas aves do grupo 1 (G1) e grupo 2 (G2), respectivamente. Nos dias 1, 4, 7 e 14 pós inoculação (dpi) foram coletados pool de fezes de cada gaiola, como também, swabs cloacais individuais. Ao $14^{\circ} \mathrm{dpi}$, todos os pintos foram eutanasiados e coletados fígado, baço, pulmão, ceco e intestino para processamento microbiológico. Observou-se mortalidade nas aves do G2 (6,25\%). O período em que o maior percentual de aves apresentavam sinal clínico de diarreia foi o $4^{\circ}$ dpi, não sendo observado nenhum quadro aos $14^{\circ}$ dpi. Os resultados de swabs cloacais mostraram eliminação bacteriana em $68,8 \%$ e $53,1 \%$ de aves dos grupos G2 e G1 respectivamente no $1^{\circ}$ dpi. Adicionalmente, ao analisar as amostras fecais, evidenciou-se alta taxa de eliminação bacteriana nos quatros períodos de observação, com uma menor taxa de excreção no $4^{\circ}$ dpi $(62,5 \%)$ em ambos os grupos. As aves do G2 apresentaram-se positivas para o patógeno no intestino (74,2\%), o grupo G1 apresentou a menor taxa no pulmão (29\%) e ambos os grupos com positividade superior a $50 \%$ nas amostras de fígado e cecos. Os resultados revelaram que pintos infectados com cepa de Salmonella Typhimurium, originária de pombos, são passíveis de albergarem o patógeno em diversos órgãos, assim como de apresentarem simultaneamente quadros de diarreia com significativos níveis de excreção bacteriana nas fezes.

Palavras-chave: Infecção experimental. Pintos. Salmonella Typhimurium. Saúde pública.

\section{Introduction}

The Salmonella bacterium, a member of the Enterobacteriaceae family, causes food infections in humans and animals worldwide (PASMARS et al., 2008; LAN et al., 2009). Among more than 2,500 Salmonella serotypes described, the Typhimurium serotype has been associated with cases of human gastroenteritis in many countries, including Brazil (FERNANDES et al., 2006; GHILARDI et al., 2006).

Subclinical infection of animals often results in chronically or intermittently asymptomatic hosts whose feces rapidly disseminate the bacteria (PORWOLLIK; MC CLELLAND, 2003; BERCHIERI JÚNIOR; FREITAS NETO, 2009). Regarding public health, pigeons (Columba livia) play an important role in the transmission of salmonellosis (SOUSA et al., 2010;
ALBUQUERQUE et al., 2013). In these birds, the Typhimurium serotype persists chronically inside macrophages, resulting in the long-term infection of the flock (PASMARS et al., 2008).

Despite numerous technological and sanitary improvements, poultry industry products continue to cause an increasing number of cases of salmonellosis (SHINOHARA et al., 2008), generating economic loss and posing a threat to public health. In fact, the consumption of chicken and eggs represents the main cause of human infection by this pathogen (BAUMLER et al., 2000).

Among Salmonella serotypes, the Typhimurium warrants concern for its potential to severely afflict young chicks and to remain hidden in asymptomatic birds for several weeks (BARROW et al., 1988; SCHLUNDT et al., 2004), favoring the spread of the pathogen. Rocha e Silva et al. (2014) isolated 
this serotype from domestic pigeons, providing evidence for a potential path of transmission of Typhimurium to industrial birds.

Given the potentially devastating impacts of Salmonella Typhimurium(ST) to the poultry industry and to public health, the study of epidemiologic and pathologic patterns of this microorganism in one-day-old chicks should provide crucial insights for the control of infection in avian flocks. Thus, we have evaluated the mortality rate of chicks inoculated with ST isolated from pigeon (Columba livia), while assessing for signs of diarrhea and septicemia.

\section{Methods and Materials}

Birds

Experimental procedures were conducted in the Ornithology Sector facilities of the State University of Ceará (UECE) with 70 one-day-old Ross broiler chicks. Chicks were randomly assigned to two experimental groups (G1 and G2) with 32 birds in each, and a control group with six birds. Chicks were housed in 22x21x16 cm cages at a density of 4 birds per cage. During the experimental period, every chick received autoclaved water ad libitum. We provided commercial feed, and kept temperature and light cycles according to the parameters defined for the Ross breed.

This work was approved by the Committee for Animal Welfare of the UECE, under protocol number 10244384-0/22.

\section{Pre-inoculation bacterial monitoring}

Before the experiments, the commercial feed and all the birds were tested for Salmonella spp. according to Zancan et al. (2000), with modifications. Individual swabs of the cloaca were collected, soaked with selenite cystine broth with novobiocin (SCNov) $(40 \mu \mathrm{g} / \mathrm{mL})$, plated in brilliant-green agar
(BBL), and incubated for $24 \mathrm{~h}$ at $37^{\circ} \mathrm{C}$. After this period, we assessed for Salmonella colonies. When a negative result was obtained, a second aliquot of the SCNov broth was plated to confirm results. Testing of the feed was performed with $1 \mathrm{~g}$ for every $40 \mathrm{~kg}$ of product diluted in SCNov broth (1:10), plated, incubated and assessed as above.

The six chicks randomly assigned to the control group were euthanized before the beginning of experiments, and fragments of liver, spleen, lung, cecum and intestine were aseptically collected. Tissue samples were macerated separately and conditioned in tubes containing buffered peptone water $(0.1 \%)$ during $24 \mathrm{~h}$ at $37^{\circ} \mathrm{C}$. After this period, an aliquot was transferred to a new tube containing SCNov broth and incubated for $24 \mathrm{~h}$ at $37{ }^{\circ} \mathrm{C}$. Samples were then plated in BBL, incubated for $24 \mathrm{~h}$ at $37^{\circ} \mathrm{C}$ and assessed for Salmonella colonies.

\section{Inoculum preparation}

The inocula were prepared from nalidixic acid resistant Salmonella Typhimurium (STNal') bacteria isolated from pigeon (Columba livia) from the Ornithology Study Laboratories - LABEO (ROCHA e SILVA et al., 2014). Inocula were prepared as per Berchieri Júnior et al. (2001) with modifications: bacterial cultures were conditioned in $5 \mathrm{~mL}$ of buffered peptone water $(0.1 \%)$ and incubated for $24 \mathrm{~h}$ at $37^{\circ} \mathrm{C}$. After this period, colony forming unities (CFU) were determined by serial dilution (MILES et al., 1938), and two different inocula were generated $\left(2 \times 10^{5} \mathrm{CFU} / 0.4 \mathrm{~mL}\right.$ and $7 \times 10^{6} \mathrm{CFU} / 0.7 \mathrm{~mL}$ of STNal ${ }^{\mathrm{r}}$.

\section{Inoculation with Salmonella Typhimurium}

Birds were inoculated in the neck with the aid of a cannula coupled to a $1 \mathrm{~mL}$ syringe. Volumes varied between 0.4 and $0.7 \mathrm{ml}$ containing $10^{5}$ and $10^{6}$ CFUs respectively for birds in G1 and G2. 


\section{Post-inoculation monitoring}

Dead chicks were counted daily and, at 1, 4, 7 and 14 days post-inoculation (dpi), cloacal swabs were performed, as described above, to determine the excretion of STNalr. At the same dpi, we conducted microbiological analyses of the feces collected from each cage with four chicks. At 14 dpi, surviving chicks were euthanized and samples of liver, spleen, lung, cecum an intestine were collected for microbiological processing.

\section{Microbiological processing}

Swabs were processed as described above. Fecal and macerated tissue samples were separately placed in tubes containing buffered peptone water $(0.1 \%)$ and incubated for $24 \mathrm{~h}$ at $37^{\circ} \mathrm{C}$. Afterwards, samples were transferred to tubes containing $\mathrm{SCNov}$ and again incubated for $24 \mathrm{~h}$ at $37^{\circ} \mathrm{C}$. Finally, samples were plated in $\mathrm{BBL}$ containing nalidixic acid (100 $\mu \mathrm{g} / \mathrm{mL})\left(\mathrm{VBNal}^{\mathrm{r}}\right)$ and incubated for $24 \mathrm{~h}$ at $37^{\circ} \mathrm{C}$. Samples that developed colonies with Salmonella Typhimurium characteristics (HOLT et al., 1994;
GAST et al., 1997) were submitted to serology using polyvalent serum (Difco®).

\section{Statistical analysis}

Experimental groups were compared regarding positivity for STNal ${ }^{\mathrm{r}}$ found in swab, fecal and tissue samples, as well as regarding the observations of clinical signs of diarrhea. To this end, we applied the non-parametric chi-squared test with Yates correction or the Fisher exact test as indicated; a significance level of 5\% was used.

\section{Results}

Only in group G2, which received the highest bacterial concentration, did we observe any mortality. At 6 dpi one chick died and a second one at $7 \mathrm{dpi}$, resulting in a $6.25 \%$ rate. Clinical signs of diarrhea were not observed at 14 dpi but were present in every other day (Table 1). The highest incidence of diarrhea were seen at 4 dpi when $78.1 \%$ and $75 \%$ of the birds in $\mathrm{G} 1$ and $\mathrm{G} 2$, respectively, were affected.

Table 1. Absolute (n) and relative (\%) number of chicks with diarrhea in different periods post inoculation.

\begin{tabular}{lcccccccc}
\hline \multirow{3}{*}{ Group/Concentration } & \multicolumn{8}{c}{ Days post inoculation } \\
\cline { 2 - 10 } & \multicolumn{2}{c}{$\mathrm{D} 1$} & \multicolumn{3}{c}{$\mathrm{D} 4$} & $\mathrm{D} 7$ & $\mathrm{D} 14$ \\
$\mathrm{nyyyyyyyyy} \mathrm{G} 1 / 10^{5}$ & $\mathrm{n} / \mathrm{N}$ & $(\%)$ & $\mathrm{n} / \mathrm{N}$ & $(\%)$ & $\mathrm{n} / \mathrm{N}$ & $(\%)$ & $\mathrm{n} / \mathrm{N}$ & $(\%)$ \\
$\mathrm{nyyyyyyyy} \mathrm{G} 2 / 10^{6}$ & $13 / 32$ & 40.6 & $25 / 32$ & 78.1 & $21 / 32$ & 65.6 & $0 / 31^{*}$ & 0.0 \\
\hline
\end{tabular}

*Accidental death

There were no significant differences between groups ( $p>0.05)$.

Table 2 displays the percentage of samples positive for $\mathrm{STNal}^{\mathrm{r}}$ after direct plating in agar (i.e., with no incubation in SCNov broth) and after $24 \mathrm{~h}$ incubation in SCNov broth. Regardless of the group, a higher percentage of positivity was found after $24 \mathrm{~h}$ incubation. At $1 \mathrm{dpi}$, bacterial elimination was found in $68.8 \%$ and $53.1 \%$ of G2 and G1 birds, respectively. At $4 \mathrm{dpi}$, these percentages were the highest at $90.6 \%$ and $87.5 \%$. At the last day, $84.4 \%$ of G1 birds eliminated bacteria versus $66.6 \%$ observed among G2 chicks (Table 2). 
Table 2. Absolute (n) and relative (\%) number of ST-positive cloacal swabs at different time points.

\begin{tabular}{lccccccccc}
\hline & & \multicolumn{8}{c}{ Days post inoculation } \\
\hline \multirow{2}{*}{ Time } & \multirow{2}{*}{ Group/Dose } & \multicolumn{2}{c}{ D1 } & \multicolumn{2}{c}{ D4 } & D7 & \multicolumn{2}{c}{ D14 } \\
\cline { 3 - 10 } & & $\mathrm{n} / \mathrm{N}$ & $(\%)$ & $\mathrm{n} / \mathrm{N}$ & $(\%)$ & $\mathrm{n} / \mathrm{N}$ & $(\%)$ & $\mathrm{n} / \mathrm{N}$ & $(\%)$ \\
\hline \multirow{2}{*}{$0 \mathrm{~h}$} & $\mathrm{G} 1 / 10^{5}$ & $2 / 32$ & 6.3 & $0 / 32$ & 0.0 & $1 / 32$ & 3.3 & $0 / 31^{*}$ & 0.0 \\
& $\mathrm{G} 2 / 10^{6}$ & $5 / 32$ & 15.6 & $0 / 32$ & 0.0 & $1 / 30$ & 6.3 & $0 / 30$ & 0.0 \\
\hline \multirow{2}{*}{$24 \mathrm{~h}$} & $\mathrm{G} 1 / 10^{5}$ & $17 / 32$ & 53.1 & $28 / 32$ & 87.5 & $15 / 32$ & 46.9 & $27 / 31^{*}$ & 87.1 \\
& $\mathrm{G} 2 / 10^{6}$ & $22 / 32$ & 68.8 & $29 / 32$ & 90.6 & $19 / 30$ & 63.3 & $20 / 30$ & 66.6 \\
\hline
\end{tabular}

*Accidental death

$\chi^{2}$ - There were no significant differences in the number of positive samples between concentrations within each method ( $\left.p>0.05\right)$. $0 \mathrm{~h}$ - Samples soaked in selective broth and immediately plated in agar.

$24 \mathrm{~h}-$ Samples plated after $24 \mathrm{~h}$ incubation in selective brot.h

The analysis of fecal material also revealed elevated rates of bacterial elimination at the four sampling time points (Table 3). The lowest rates were observed at 4 dpi when both experimental groups had $62.5 \%$ of positive samples. At 1 and 7 dpi, positivity was $100 \%$ and $87.5 \%$ for G1 and G2, respectively, and these values inverted at $14 \mathrm{dpi}$.

Table 3. Absolute (n) and relative (\%) number of ST-positive fecal samples at different time points.

\begin{tabular}{lcccccccc}
\hline Group/Concentration & \multicolumn{8}{c}{ Days post inoculation } \\
\cline { 2 - 11 } & \multicolumn{2}{c}{$\mathrm{D} 1$} & \multicolumn{3}{c}{$\mathrm{D} 4$} & $\mathrm{n} 7$ & \multicolumn{2}{c}{$\mathrm{D} 14$} \\
\cline { 2 - 11 } $\mathrm{G} 1 / 10^{5}$ & $8 / \mathrm{N}$ & $(\%)$ & $\mathrm{n} / \mathrm{N}$ & $(\%)$ & $\mathrm{n} / \mathrm{N}$ & $(\%)$ & $\mathrm{n} / \mathrm{N}$ & $(\%)$ \\
$\mathrm{nyyyyyyyyyy} \mathrm{G} 2 / 10^{6}$ & $7 / 8$ & 87.5 & $5 / 8$ & 62.5 & $8 / 8$ & 100 & $7 / 8$ & 87.5 \\
\hline
\end{tabular}

There were no significant differences between groups $(\mathrm{p}>0.05)$.

The analysis of tissues collected at 14 dpi showed that $\mathrm{G} 2$ birds had a highest frequency of STNal ${ }^{\mathrm{r}}$ in the intestine (74.2\%), whereas for G1 chicks this was the third highest frequency (56.6\%). In both groups, positive liver and cecum samples represented more than $50 \%$ of the total. In addition, G1 birds had the lowest incidence of lung infection (29\%) compared to $40 \%$ observed in G2 birds (Table 4).

Table 4. Absolute (n) and relative (\%) number of ST-positive tissue samples at 14 days post inoculation.

\begin{tabular}{lcccc}
\hline \multirow{2}{*}{ Tissue } & \multicolumn{3}{c}{ Group/Bacterial concentration } & G2/10 \\
\cline { 2 - 5 } & $\mathrm{n} / \mathrm{N} 1 / 10^{5}$ & & $\mathrm{n} / \mathrm{N}$ & $(\%)$ \\
\hline Liver & $18 / 31$ & 58.1 & $15 / 30$ & 50.0 \\
Spleen & $10 / 31$ & 32.3 & $12 / 30$ & 40.0 \\
Intestine & $23 / 31$ & 74.2 & $17 / 30$ & 56.6 \\
Cecum & $16 / 31$ & 51.6 & $16 / 30$ & 53.3 \\
Lung & $9 / 31$ & 29.0 & $12 / 30$ & 40.0 \\
\hline
\end{tabular}

There were no significant differences between groups $(\mathrm{p}>0.05)$. 
No statistically significant differences were observed between groups for any of the measurements $(\mathrm{p}>0.05)$.

\section{Discussion}

Two potential explanations exist for the relatively low mortality observed in both chick groups. The first is related to the bacterial serotype used, isolated from a different order of birds. Certain host species display more severe infection cases with better microorganism adaptation (FOLEY; LYNNE, 2008). In the present work, the ST was isolated from a free-range domestic pigeon, which displayed clinical signs of salmonellosis and died (ROCHA e SILVA et al., 2014). The microorganism was possibly well adapted to the pigeon and may have been the cause of death. This serotype, however, when inoculated in chicks, did not maintain this level of pathogenicity. Sousa et al. (2013) obtained similar results after orally inoculating chicks with $1.2 \times 10^{8} \mathrm{CFU} / \mathrm{mL}$ of Salmonella isolated from pigs raised near aviaries. These researchers did not register any deaths in the 21-day experimental period. The second explanation for the low mortality could reside in the relatively low concentrations used in both experimental groups. Previous work with bacterial concentrations above $7 \times 10^{6} \mathrm{CFU} / 0.7$ $\mathrm{mL}$ has not resulted in chick mortality. For example, Brito et al. (1995) observed that one-day old chicks orally inoculated with $10^{8} \mathrm{CFU} / 0.2 \mathrm{~mL}$ did not display clinical signs of salmonellosis or mortality. Withanage et al. (2005) reached similar results with one-week old chicks inoculated with $10^{8} \mathrm{CFU} / 0.1$ $\mathrm{mL}$ of Salmonella.

Post-inoculation cloacal swabs were more often positive after $24 \mathrm{~h}$ incubation in SCNov when compared with samples that were only soaked in the broth, indicating that the period of incubation affects the results. This finding is probably associated with the selectivity of the broth, which inhibits the additional microbiota present in the sample (BAGER; PETERSEN, 1991; ARROYO;
ARROYO, 1995), allowing for better growth of Salmonella.

The highest frequency of positive cloacal swab samples was detected at $4 \mathrm{dpi}$ for both treatments, and reached $90.6 \%$ of the birds in the group inoculated with $7 \times 10^{6} \mathrm{CFU} / 0.7 \mathrm{~mL}$. Sousa et al. (2013), using ST isolated from pigs orally inoculated in chicks, observed that $100 \%$ of cloacal swabs were positive at 1 and $8 \mathrm{dpi}$. These authors used a concentration of $1.2 \times 10^{8} \mathrm{CFU} / \mathrm{mL}$, which may explain the elevated number of positive samples.

The microbial load used in this study promoted a high frequency of ST elimination in the fecal samples. Beal et al. (2004) pointed to the importance of knowing ST excretion frequency, because, they observed, experimentally infected broiler chicks may have intestinal colonization in $90 \%$ of the cases and still show no clinical signs of salmonellosis. Although we observed diarrhea in the first three sampling time points, in the fourth and last time point, these signs could not be observed possibly because of the chick immune response.

These results further support the idea that, in the poultry industry, asymptomatic birds may favor the long-term persistence of this pathogen increasing the risks of contamination and propagation within the flock (SIVULA et al., 2008). Moreover, during slaughter, there is a greater risk that carcasses might be contaminated (BEAL et al., 2004; SIVULA et al., 2008), increasing the risk to human health.

The experimental doses used in this study promoted a relevant degree of septicemia, as positive results were observed in samples from all analyzed tissues. Previous studies also showed a greater percentage of positive results in the intestine relative to the liver and spleen (SOUSA et al., 2013). These authors showed that, at $15 \mathrm{dpi}$, ST was present in all cecum samples $(n=63)$, but only $25 \%$ of birds had ST in the liver and spleen. The presence of ST in the organs of birds at $14 \mathrm{dpi}$, in this study, may be explained by the age of chicks. According to Barrow (2000), during the first days of life, the 
immune systems of chicks are not fully developed. Thus, these birds are highly susceptible to the invasion and colonization of the intestinal tract, and other organs, by ST (BAILEY et al., 1994; BYRD et al., 1998).

We only analyzed tissues at $14 \mathrm{dpi}$, when the ST was detected in different organs. However, another investigation has shown that ST dissemination may occur shortly after inoculation. Brito et al. (1995) isolated the pathogen from the small intestine, cecum, liver and spleen only $3 \mathrm{~h}$ after oral inoculation, when birds showed no clinical signs of disease.

The incidence of diarrhea at 4 and 7 dpi was elevated. Withanage et al. (2005) also found diarrhea in ST-inoculated chicks. This condition suggests that birds were susceptible to clinical manifestations of disease at the dose used (BERCHIERI JÚNIOR et al., 2001). However, according to Beal et al. (2004), ST-infected birds may show no signs of disease.

Despite periods during which most chicks displayed the clinical signs of salmonellosis, no signs of disease were detected in all or most of the birds during the rest of the experiment. The absence of diarrhea may be associated with particularly resistant chick lineages or genetic backgrounds (RIBEIRO et al., 2005) and these birds that seemed healthy even at 14 dpi could, therefore, act as reservoirs of the disease, and might trigger infection in other chicks (VAN IMMERSEEL et al., 2004), through their feces (GAST, 2003).

\section{Conclusions}

These results show that chicks infected with ST from pigeon may house the pathogen in several organs, and simultaneously display diarrhea along with high levels of fecal bacterial excretion.

\section{Acknowledgments}

The authors thank the Ceará Foundation for the Support of Scientific and Technological
Development (FUNCAP) for the doctoral scholarship and the Laboratory of Ornithological Studies (LABEO/FAVET/UECE) for the technical support.

\section{References}

ALBUQUERQUE, Á. H.; CARDOSO, W. M.; TEIXEIRA, R. S. C.; LOPES, E. S.; SALES, R. J. P. F.; HORN, R. V.; GOMES-FILHO, V. J. R. Dissemination of Salmonella Enteritidis by experimentally-infected pigeons. Revista Brasileira de Ciência Avícola, Campinas, v. 15, n. 3, p. 211-215, 2013.

ARROYO, G.; ARROYO, J. A. Efficiency of different enrichment and isolation procedures for the detection of Salmonella serotypes in edible offal. Journal of Applied Microbiology, Oxford, v. 79, n. 4, p. 360-367, 1995.

BAGER, F.; PETERSEN, J. Sensitivity and specificity of different methods for the isolation of Salmonella from pigs. Acta Veterinaria Scandinavica, Copenhagen, v. 32, n. 4, p. 473-81, 1991.

BAILEY, J. S.; COX, N. A.; BERRANG, M. E. Hatcheryacquired Salmonellae in broiler chicks. Poultry Science, Champaign v. 73, n. 7, p. 1153-1157, 1994.

BARROW, P. A. The paratyphoid salmonellae. Revue Scientifique et Technique-Office International des Epizooties, Paris, v. 19, n. 2, p. 351-375, 2000.

BARROW, P.; SIMPSON, J. M.; LOVELL, M. A. Intestinal colonization in the chicken by food-poisoning Salmonella serotypes; microbial characteristics associated with faecal excretion. Avian Pathology, Cambs, v. 17, n. 13, p. 571-588, 1988.

BAUMLER, A. J.; HARGIS, B. M.; TSOLIS, R. M. Tracing the origins of Salmonella outbreaks. Science, Washington, v. 287, n. 5450, p. 52-52, 2000.

BEAL, R. K.; WIGLEY, P.; POWERS, C.; HULME, S. D.; BARROW, P. A.; SMITH, A. L. Age at primary infection with Salmonella enterica serovar Typhimurium in the chicken influences persistence of infection and sub sequent immunity to re-challenge. Veterinary Immunology and Immunopathology, Amsterdam, v. 100, n. 3-4, p. 151-164, 2004.

BERCHIERI JÚNIOR, A.; FREITAS NETO, O. C. Salmoneloses. In: BERCHIERI JÚNIOR, A.; SILVA, E. N.; DI FÁBIO, J.; SESTI, L.; ZUANAZE, M. A. F. Doenças das aves. 2. ed. Campinas: Ed. FACTA, 2009. p. 435-454. 
BERCHIERI JUNIOR, A.; MURPHY, A.; MARSTON, K.; BARROW, P. A. Observations on the persistence and vertical transmission of Salmonella enterica serovars Pullorum and Gallinarum in chickens: effect of bacterial and host genetic background. Avian Pathology, Cambs, v. 30, n. 3, p. 221-231, 2001.

BRITO, J. R. F.; XU, Y.; HINTON, M.; PEARSON, G. R. Pathological findings in the intestinal tract and liver of chicks after exposure to Salmonella serotypes Typhimurium or kedougou. British Veterinary Journal, London, v. 151, n. 3, p. 311-323, 1995.

BYRD, J. A.; CORRIE, R. D. E.; DELOACH, J. R.; NISBET, D. J.; STANKER, L. H. Horizontal transmission of Salmonella typhimurium in broiler chicks. The Journal of Applied Poultry Research, Oxford, v. 7, n. 1, p. 75-80, 1998.

FERNANDES, S. A.; TAVECHIO, A. T.; GHILARDI, A. C. R.; DIAS, A. M. G.; ALMEIDA, I. A. Z. C.; MELO, L. C. V. Salmonella serovars isolated from humans in Sao Paulo State, Brazil, 1996-2003. Revista do Instituto de Medicina Tropical, São Paulo, v. 48, n. 4, p. 179-184, 2006.

FOLEY, S. L.; LYNNE, A. M. Food animal-associated Salmonella challenges: pathogenicity and antimicrobial resistance. Journal of Animal Science, Champaign, v. 86, p. 173-187, 2008. Supplement 14.

GAST, R. K. Salmonella Infections. In: SAIF, Y. M. (Ed.). Diseases of poultry. $11^{\text {th }}$ ed. Ames: A publication of American Association of Avian Pathologists, Iowa State Press, 2003. p. 567-613.

GAST, R. K.; PORTER JUNIOR, R. E.; HOLT, P. S. Applying tests for specific yolk antibodies to predict contamination by Salmonella Enteritidis in eggs from experimentally infected laying hens. Avian Diseases, Amherst, v. 41, n. 1, p. 195-202, 1997.

GHILARDI, A. C.; TAVECHIO, A. T.; FERNANDES, S. A. Antimicrobial susceptibility, phage types, and pulse types of Salmonella Typhimurium, in São Paulo, Brazil. Memórias do Instituto Oswaldo Cruz, Rio de Janeiro, v. 101, n. 3, p. 281-286, 2006.

HOLT, J. G.; KRIEG, N. R.; SNEATH, P. H.; STALEY, J. T.; WILLIAMS, S. T. Group 5: Facultatively anaerobic gram-negative rods. In: HOLT, J. G.; KRIEG, N. R.; SNEATH, P. H.; STALEY, J. T.; WILliAMS, S. T. Bergey's: manual of determinative bacteriology. $9^{\text {th }}$ ed. Baltimore: W. \& Williams, 1994. p. 175-252.

LAN, R.; REEVES, P. R.; OCTAVIA, S. Population structure, origins and evolution of major Salmonella enterica clones. Infection Genetics and Evolution, Amsterdam, v. 9, n. 5, p. 996-1005, 2009.
MILES, A. A.; MISRA, S. S.; IRWIN, J. O. The estimation of the bactericidal power of the blood. The Journal of Hygiene, London, v. 38, n. 6, p. 732-749, 1938.

PASMARS, F.; BEART, K.; MARTEL, A.; MELOU, A. B.; BACKER, P.; BOEVER, S. Induction of the carrier state in pigeons infected with Salmonella enterica subspecies enterica serovar typhimurium PT99 by treatment with florfenicol: a matter of pharmacokinetics. Antimicrobial Agents and Chemotherapy, Bethesda, v. 52, n. 3, p. 954-961, 2008.

PORWOLLIK, S.; MC CLELLAND, M. Lateral gene transfer in Salmonella. Microbes and Infection, Paris, v. 5, n. 11, p. 977-989, 2003.

RIBEIRO, S. A. M.; BERCHIERI JUNIOR, A.; ORSI, M. A.; MENDONÇA, A. O.; FERRATI, A. R. Experimental infection by Salmonella enterica subsp enterica serovar Kottbus in day-old broiler chickens. Brazilian Journal Poultry Science, Campinas, v. 7, n. 2, p. 107-112, 2005.

ROCHAE SILVA, R. C.; CARDOSO, W. M.; TEIXEIRA, R. S. C.; ALBUQUERQUE, Á. H.; VASCONCELOS, R. H.; LOPES, E. S.; GOMES FILHO, V. J. R.; ALMEIDA, C. P.; SANTOS, I. C. L; MACHADO, D. N.; LIMA, S. V. G.; CARNEIRO, I. S. Detecção de Salmonella enterica subsp enterica (O:4,5:i) e Salmonella enterica subsp. Typhimurium em pombos doméstico de vida livre (Columba livia). Arquivo Brasileiro de Medicina Veterinária e Zootecnia, Belo Horizonte, v. 66, n. 5, p. 1435-1438, 2014.

SCHLUNDT, J.; TOYOFUKU, H.; JANSEN, J.; HERBST, S. A. Emerging food-borne zoonoses. Revue Scientifique et Technique-Office International des Epizooties, Paris, v. 23, n. 2, p. 513-533, 2004.

SHINOHARA, N. K. S.; BARROS, V. B.; JIMENEZ, S. M. C.; MACHADO, E. C. L.; DUTRA, R. A. F.; LIMA FILHO, J. L. Salmonella spp., importante agente patogênico veiculado em alimentos. Ciência \& Saúde Coletiva, Rio de Janeiro, v. 13, n. 5, p. 1675-1683, 2008.

SIVULA, C. P.; BOGOMOLNAYA, L. M.; ANDREWSPOLYMENIS, H. L. Comparison of cecal colonization of Salmonella enterica serotype Typhimurium in white leghorn chicks and Salmonella-resistant mice. BMC Microbiology, London, v. 8, n. 1, p. 1-13, 2008.

SOUSA E.; BERCHIERI JÚNIOR, A.; PINTO, A. A.; MACHADO, R. Z.; CARRASCO, A. O. T.; MARCIANO, J. A.; WERTHER, K. Prevalence of Salmonella spp. Antibodies to Toxoplasma gondii, and Newcastle disease virus in feral pigeons (Columba livia) in the city of Jaboticabal, Brazil. Journal of Zoo and Wildlife Medicine, Lawrence, v. 41, n. 4, p. 603-607, 2010. 
SOUSA, E. de; WERTHER, K.; BERCHIERI JUNIOR, A.; ALMEIDA, A. M.; ARDISSON, F. A.; SILVA, A. C.; CANDIOTO, C. G. I.; FERNANDES, S. A. Experimental infection of one-day-old chicks with salmonella serotypes previously isolated from poultry facilities, wild birds, and swine. Revista Brasileira de Ciência Avícola, Campinas, v. 15, n. 4, p. 301-305, 2013.

VAN IMMERSEEL F.; DE BUCK, J.; PASMANS, F.; BOHEZ, L.; BOYEN, F.; HAESEBROUCK, F.; DUCATELLE, R. Intermittent long-term shedding and induction of carrier birds after infection of chickens early posthatch with a low or high dose of salmonella enteritidis. Poultry Science, Savoy, v. 83, n. 11, p. 19111916, 2004.
WITHANAGE, G. S.; WIGLEY, P.; KAISER, P.; MASTROENI, P.; BROOKS, H.; POWERS, C.; BEAL, R.; BARROW, P.; MASKELL, D.; MCCONNELL, I. Cytokine and chemokine responses associated with clearance of a primary Salmonella enterica serovar Typhimurium infection in the chicken and in protective immunity to rechallenge. Infection and Immunity, Washington, v. 73, n. 8, p. 5173-82, 2005.

ZANCAN, F. T.; BERCHIERI JUNIOR, A.; FERNANDES, A. S.; GAMA, N. M. S. Q. Salmonella spp. investigation in transport boxes of day-old birds. Brazilian Journal of Microbiology, São Paulo, v. 31, n. 3, p. 229-232, 2000. 
